\title{
Silicon in C-3 grasses: Effects on forage quality and sheep preference
}

\author{
GLENN E. SHEWMAKER, H.F. MAYLAND, R.C. ROSENAU, AND K.H. ASAY
}

\section{Abstract}

Silicon in forage reduces dry matter digestibility and may reduce grazing preference. Two studies were conducted with the following objectives: (1) to evaluate a method of determining grazing preference, and (2) to characterize the distribution and solubility of silicon in 31 accessions of $\mathbf{C}-3$ grasses and relate these traits to grazing preference and estimated forage digestibility. Forage samples were clipped at the beginning of each 7 to 10-day grazing period corresponding to 6 phenological stages of the Agropyron sp. Samples were washed and analyzed for acid detergent fiber (ADF), neutral detergent fiber (NDF), and silicon in ADF and NDF residues. Leaf silicon concentrations increased from the vegetative to seed-ripe stage. Genera were aligned into 3 groups based on the increase in leaf silicon concentration with advancing phenological age. Silicon concentrations in leaves of $A$ gropyron, Pseudoroegneria, and Thinopyrum increased at nearly twice the rate of those in Critesion, Hordeum, Leymus and Psathyrostachys. Elymus leaves contained higher concentrations of silicon at the vegetative stage than the other groups, but the accumulation rate was intermediate. About $32 \%$ of total leaf silicon remained in NDF and $76 \%$ in ADF residues at the vegetative stage. These insoluble portions of silicon increased with aging. Preference was positively related to estimated dry matter digestibility at boot and anthesis, but was not related to fiber or silicon measurements. Leaf harshness was negatively related to preference at seed-ripe stage. Further progress in characterizing the role of silicon in C-3 forage grasses should be possible by studying a representative species from each group.

Key Words: soluble silicon, insoluble silicon, harshness score, digestiblity, Agropyron, ADF, NDF, crested wheatgrass, wildrye

Silicon $(\mathrm{Si})$ is absorbed as monosilicic acid $\left[\mathrm{Si}(\mathrm{OH})_{4}\right]$ by plant roots, transported throughout the plant, and deposited primarily in the epidermal cells, stoma, and trichomes of leaves (Jarvis 1987). Some of this silicon remains in soluble forms. Most silicon, however, is incorporated into or onto the cell wall structure or precipitated with other elements to form amorphous crystalline deposits called phytolyths (Blackman and Bailey 1971, Moore 1984). Sil-

Authors are biological technician, research soil scientist and agricultural research technician, USDA, Agricultural Research Service, Kimberly, Idaho 83341; and research plant geneticist, USDA, Agricultural Research Service, Logan, Utah $84322-6300$.

Manuscript accepted 22 September 1988. icon uptake is largely passive, i.e., taken up with the transpiration stream. However, recent evidence has demonstrated that some energy mediated uptake of silicon occurs in grasses (Jarvis 1987).

The incorporation of silicon into scabrous tissue is perceived as a defense mechanism against some insects (Moore 1984) and possibly against grazing by large herbivores (McNaughton et al. 1985). Silicon taken up by forage plants may also reduce rumen microbial accessibility to cell wall structure (Smith and Nelson 1975, Harbers et al. 1981), thereby reducing apparent digestibility of herbage (Van Soest and Jones 1968, Smith et al. 1971). Mika (1986) reported that a water-soluble form of silicon inhibited activity of cellulases and other digestive enzymes, whereas the insoluble form was chemically inert. Thus, exogenous silicon from ingested soil or dust adhering to herbage probably has little direct effect on digestibility.

Silicon, in addition to affecting forage quality, has been implicated in animal health (Jones and Handreck 1967). In some early research, urolithiasis in steers was related $(r=0.56)$ to silicon concentrations in Montana forage grasses (Parker 1957). However, Bailey (1976) later reported that frequency of urinary calculi encountered in Alberta cattle was inversely related to urine volume and water intake. This cause and effect relationship has not been resolved.

Smith et al. (1972) have reported weight gains in wether but not in ewe lambs provided $800 \mathrm{mg} \mathrm{SiO}_{2} \mathrm{~L}$ in their drinking water. Similar sex by silica interactions were also reported for rats (Smith et al. 1973), suggesting a physiological or hormonal response to the added silicon. These findings have not, however, been confirmed by other research groups.

The distribution of silicon in C-3, semiarid forage grasses and the effect of silicon on forage quality and animal preference have not been determined. These studies were initiated to develop methods and test the following hypotheses: (1) Silicon concentration in leaves of temperate grasses increases with advancing physiological maturity; (2) Rates of silicon accumulation differ among grass genera; (3) Leaf-silicon concentrations relate positively to leaf harshness and negatively to animal preference; (4) Silicon is more soluble in NDF than in ADF extractions; and (5) Silicon reduces forage dry matter digestibility.

Information on concentration and distribution of silicon in grasses will be useful for breeding and managing grasses for higher 
digestibility, or conversely, for greater insect/ herbivore resistance.

\section{Materials and Methods}

\section{Study I}

This phase of the experiment evaluated a nondestructive method of determining animal preference for forage species. A nursery was established with 9 species (Table 1) planted in a randomized, complete block having 4 replications. The plots were $2 \times 18 \mathrm{~m}$ and grasses were seeded in the fall on $20-\mathrm{cm}$ row spacings. The nursery was established on a Portneuf silt loam (coarse, silty, Durixerollic calciorthid) soil near Kimberly, Idaho.

Supplementary irrigation water and $45 \mathrm{~kg} \mathrm{~N} /$ ha were applied the next summer to promote good growth. Border areas were clean cultivated. Test plants were mowed the following September. Five nonlactating ewes grazed the regrowth in late October and early November of 1980 . Five different nonlactating ewes grazed the nursery at the seed-ripe stage (15 August to 15 September 1981). Eight lambs (each approximately $60 \mathrm{~kg}$ ) grazed the nursery from 7 through 20 May 1982, 26 May through 8 June 1982, and 15 September through 9 October 1982, at the boot, anthesis, and seed-ripe stages of Agropyron, respectively. Preference scores were subjectively rated by the degree of utilization. Utilization of each grass was estimated daily by 3 observers. Daily ratings ranged from 0 , not grazed, to 10 , heavily grazed. The values were summed over the grazing period, calculated as the percent of the most preferred accession for each phenological stage (corresponding to the Agropyrons), and subjected to analysis of variance (SAS 1985).

\section{Study II.}

A second nursery of 31 accessions, representing 26 species (Table 2), was established on the same area described for Study I. Six of the species were also evaluated in Study 1 . The individual plants were started in Conetainers ${ }^{1}$ in a greenhouse and transplanted to the field in early April. The experimental design was a randomized complete block with 1 replication. Plants were placed on $1-\mathrm{m}$ spacings with each accession occupying a $6 \times 6-\mathrm{m}$ plot (36 plants per plot). The area was fertilized with $45 \mathrm{~kg} \mathrm{~N} / \mathrm{ha}$ and irrigated to establish good growth. Border areas were tilled to eliminate other plants. Plants were clipped to $5-\mathrm{cm}$ stubble height in March of the following year to eliminate any remaining dry stalks.

Leaf harshness was ranked at the seed-ripe stage. This subjective scoring was based on 0 , very soft, to 10 , very coarse and sharp. The scoring was performed by 3 observers passing the leaves through their hands. Scores were added to make up the harshness value for each grass.

Six, 4- to 5-year-old ewes, having good teeth, were placed in the nursery for 7 to 10-day periods at times corresponding to each phenological stage of the Agropyron species. Drinking water, but not shade, was available within the enclosure. Preference was determined as described in Study I.

Subsamples of aerial herbage were harvested at a $5-\mathrm{cm}$ stubble height prior to each grazing period. Harvested samples were agitated for 1 to 2 minutes in distilled water containing Prell letergent in a concentration of $1 \mathrm{ml} / \mathrm{L}$. Samples were then rinsed in distilled water for another 1 to 2 minutes, dried at $60^{\circ} \mathrm{C}$ for 24 hours, and ground through a Wiley' mill to pass a 40-mesh screen.

Silicon in grass tissue was determined by the molybdenum blue colorimetric method (Fox et al. 1969). Silicon was also determined in residues of acid detergent fiber (ADF) and neutral detergent fiber extractions [NDF, (Goering and Van Soest 1970)]. A barleystraw reference sample was analyzed with each batch of unknowns to determine precision. All data were reported on a dry matter basis.

Insoluble silicon in the ADF and NDF residues was calculated by the equation: Insoluble $\mathrm{Si}=(\mathrm{mg} \mathrm{Si} / \mathrm{mg}$ residue)* $(\mathrm{mg}$ residue $/ \mathrm{g}$ leaf). Estimated dry matter digestibility (EDMD) of leaves was calculated by the formula: EDMD in $\mathrm{mg} / \mathrm{g}=1000-[\mathrm{mg} \mathrm{NDF} / \mathrm{g}+$ mg NDF-soluble $\mathrm{Si} / \mathrm{g}$ ].

Data were subjected to analysis of variance and regression using SAS Institute's general linear models procedure, including the Duncan's multiple range mean comparison procedure (SAS 1985). The phenological stages from vegetative through seed-ripe were assigned values of 0 through 4 , respectively. A $t$-test was used to evaluate differences between the slope coefficients (b) of silicon concentration regressed against phenological stage, for each genotype (Steele and Torrie 1960). Grass nomenclature follows the genomic system of classification (Dewey 1984). Accessions were further designated by variety (e.g., Nordan') or chromosome number (e.g., $2 n=28$ ).

\section{Results and Discussion}

Study I.

\section{Preference Methodology}

Preference scores for each stage and species were significantly different $(P<.001)$ as shown in Table 3 . The species by stage

\footnotetext{
'Reference to commercial products and services is made with the understanding that no discrimination is intended and no end orsement by the U.S. Department of Agriculture is implied.
}

Table 1. Acceasions and sheep preference as a percent of the moat preferred acceacion (Study I).

\begin{tabular}{|c|c|c|c|c|c|c|}
\hline & \multirow[b]{2}{*}{ Genus \& specie } & \multicolumn{5}{|c|}{ Relative sheep preference by year and phenological stage } \\
\hline & & $\begin{array}{l}1982 \\
\text { Boot }\end{array}$ & $\begin{array}{c}1982 \\
\text { Anthesis }\end{array}$ & $\begin{array}{c}1981 \\
\text { Seed-ripe }\end{array}$ & $\begin{array}{c}1982 \\
\text { Seed-ripe }\end{array}$ & $\begin{array}{c}1980 \\
\text { Regrowth }\end{array}$ \\
\hline \multirow{7}{*}{$\begin{array}{l}\text { Indian ricegrass } \\
\\
\text { Orchardgrass } \\
\text { Intermediate } \\
\text { wheatgrass } \\
\text { Crested } \\
\text { wheatgrass } \\
\text { Creeping foxtail } \\
\text { RS hybrid }\end{array}$} & \multirow{3}{*}{$\begin{array}{l}\text { Oryzopsis hymenoides Roem. \& Schult. } \\
\text { 'Nezpar' } \\
\text { Dactylis glomerata L. 'Pomar' }\end{array}$} & \multicolumn{5}{|c|}{-Relative Preferencel (\%) } \\
\hline & & 99 a & $100 \mathrm{a}$ & $24 \mathrm{~d}$ & $47 \mathrm{~cd}$ & $100 \mathrm{a}$ \\
\hline & & $100 \mathrm{a}$ & $84 b$ & $54 \mathrm{bc}$ & $77 \mathrm{~b}$ & $98 \mathrm{a}$ \\
\hline & Thinopyrum intermedium Host 'Tegmar' & $81 \mathrm{~b}$ & $64 \mathrm{~d}$ & $42 \mathrm{~cd}$ & $22 \mathrm{e}$ & $67 \mathrm{~b}$ \\
\hline & & & & & & \\
\hline & $\begin{array}{l}\text { Agropyron desertorum Fisch. 'Nordan' } \\
\text { Alopecurus arundinaceus Poir. 'Garrison' }\end{array}$ & $\begin{array}{l}69 \mathrm{~b} \\
70 \mathrm{~b}\end{array}$ & $\begin{array}{l}59 \mathrm{de} \\
73 \mathrm{c}\end{array}$ & $\begin{array}{r}26 \mathrm{~d} \\
100 \mathrm{a}\end{array}$ & $\begin{array}{l}45 \mathrm{~cd} \\
100 \mathrm{a}\end{array}$ & $\begin{array}{l}70 \mathrm{~b} \\
15 \mathrm{~d}\end{array}$ \\
\hline & $\begin{array}{l}\text { Elytrigia repens L. } \times \text { Pseudoroegneria } \\
\text { spicata Pursh }\end{array}$ & $45 \mathrm{c}$ & 5 & $27 \mathrm{~d}$ & $34 \mathrm{~cd}$ & $24 \mathrm{~d}$ \\
\hline \multirow{3}{*}{$\begin{array}{l}\text { Russian wildrye } \\
\text { Tall fescue } \\
\text { Regar brome }\end{array}$} & Psathyrostachys juncea Fisch. & $45 \mathrm{c}$ & 54 ef & $74 \mathrm{~b}$ & $66 \mathrm{c}$ & $6 \mathrm{~d}$ \\
\hline & $\begin{array}{l}\text { Festuca arundinacea Schreb 'Alta' } \\
\text { Bromus blebersteinil Roem. \& Schult. }\end{array}$ & $24 \mathrm{~d}$ & 18 & $25 \mathrm{~d}$ & $14 \mathrm{e}$ & $60 \mathrm{bc}$ \\
\hline & 'Regar' & $21 \mathrm{~d}$ & $\mathbf{O g}$ & $42 \mathrm{~cd}$ & $18 \mathrm{e}$ & $44 \mathrm{c}$ \\
\hline
\end{tabular}

'Means in same column followed by the same letter are not significantly different $(\boldsymbol{P}<.01)$ as determined by Duncan's multiple range test.

'Indian ricegrass was so highly preferred that it was entirely consumed in some periods. 
Table 2. Nomenchture of accesions and sheep preference sos percent of the most preferred accesaion at 4 phenological stages (Study II).

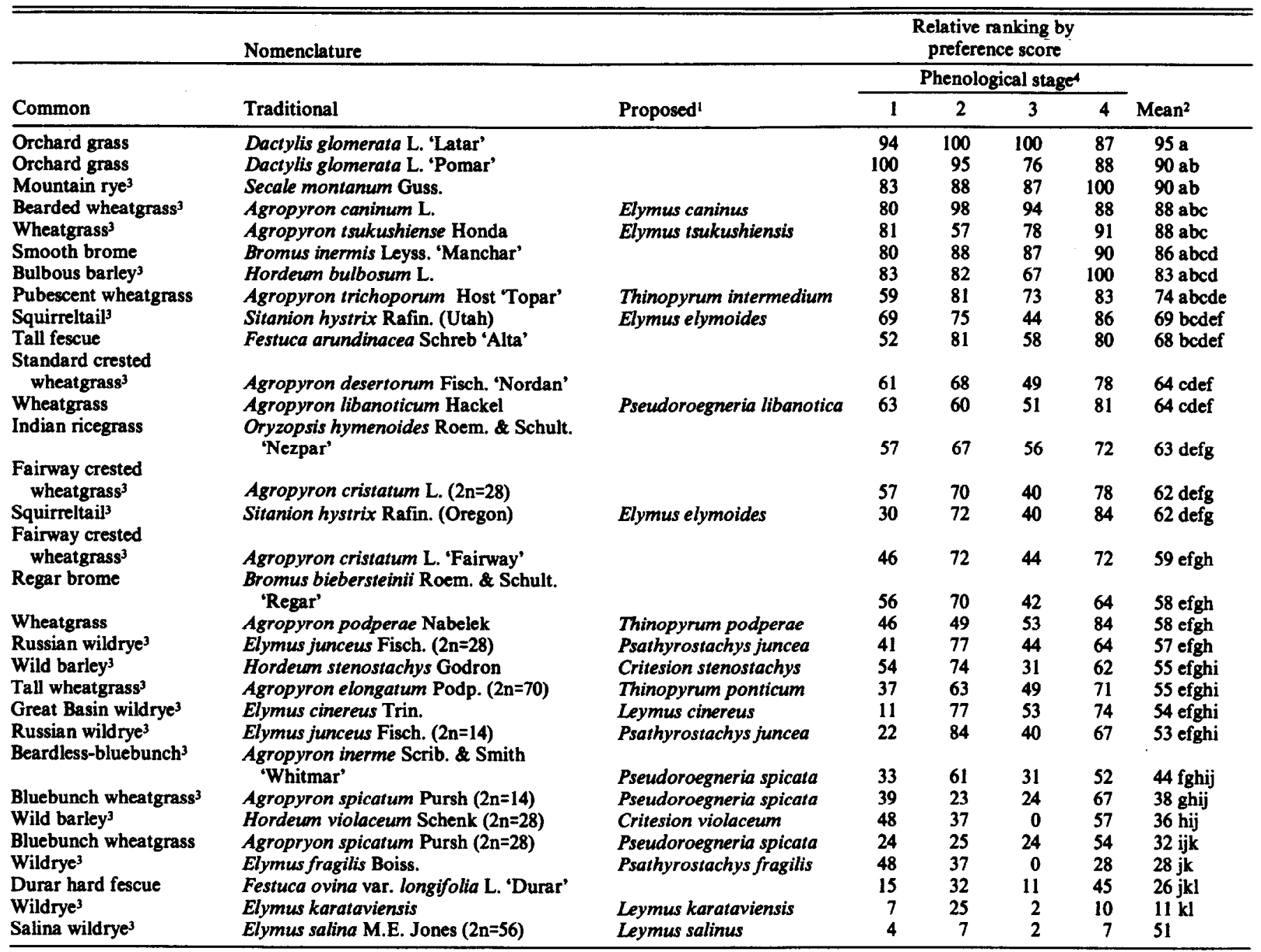

'Nomenclature follows that proposed by Dewey (1984). Accessions are listed in sequence of overall preference ranking.

2Means with the same letter are not significantly different $(P<.01)$ as determined by Duncan's multiple range test.

${ }^{3}$ Accessions selected for ADF and NDF determinations.

'Phenological stages are: $1,2,3$, and 4 representing vegetative, boot, anthesis, and seed-ripe, respectively.

interaction was also significant $(P<.001)$, suggesting that relative differences among species were not consistent at the different stages of growth. Indian ricegrass (Table 1) was highly preferred and the stand was greatly weakened. Orchard grass was also highly preferred except at the seed-ripe stage. Creeping foxtail and Russian wildrye were the more preferred species at the seed-ripe stage. This is probably because both species grew more actively and remained greener throughout the season. Preference changed with season of use.

Table 3. Analysis of variance of relative' preference for 9 species at boot, anthesis, seed-ripe (2 years) and regrowth phenological stages (Study I).

\begin{tabular}{lcc}
\hline \hline Source & df & $\begin{array}{c}\text { Mean } \\
\text { squares }\end{array}$ \\
\hline Blocks (B) & 3 & $563^{* *}$ \\
Species (Sp) & 8 & $8316^{* *}$ \\
Sp $\times$ B & 24 & 100 \\
Stage (St) & 4 & $1600^{* *}$ \\
St $\times$ Sp & 32 & $2984^{* *}$ \\
\hline
\end{tabular}

IRelative preference is calculated as the pencent of the maximum preference score (mean for an accession) for that grazing period.
There was a significant block effect $(P<.01)$ which was attributed to animal behavior (Table 3). Drinking water and the gate through which the sheep entered at the beginning of the grazing trials were located near the corner of the nursery. Preference scores were highest for the block nearest this corner and lowest for the block farthest away, even though the distance was less than $50 \mathrm{~m}$. Nevertheless, the preference scoring consistently ranked the species in the same order, as shown by the nonsignificant species $X$ block interaction. This established the repeatability of the scoring system which was then used in the subsequent evaluation of the 31 accessions in Study II.

Study II.

\section{Silicon in Leaves}

In each accession silicon concentrations in leaves increased linearly as the grasses matured. Silicon accumulation rates were not different between species within a given genera $(P<.05)$. The accumulation rates (b) for individual accessions and for accessions grouped by genera were different from zero $(P<.05)$ in all cases (data not shown). Data were then composited by genera and submitted to regression analysis. Coefficients were then compared with each other in a pair-wise testing for similarities. Based on these tests the 8 genera were aligned into 3 distinct groups (Table 
Table 4. Rezreasion of sillcun accumulation (my/z) in trass leaves on phenological stage, where $\times(0-4)$ represents the phenologleal stages vegetative, boot, anthevis, dough, and seed-ripe, respectively.

\begin{tabular}{|c|c|c|c|c|c|c|}
\hline \multirow[b]{2}{*}{ Genera } & \multirow{2}{*}{$\begin{array}{l}\text { Degrees of } \\
\text { freedom }\end{array}$} & \multirow{2}{*}{$\begin{array}{c}\mathbf{a} \\
\text { (intercept) }\end{array}$} & \multirow{2}{*}{$\begin{array}{c}b \\
\text { (slope) }\end{array}$} & \multirow[b]{2}{*}{$\mathbf{r}$} & \multicolumn{2}{|c|}{ Standard error of } \\
\hline & & & & & Intercept & Slope \\
\hline $\begin{array}{l}\text { Group I' } \\
\text { Group II² } \\
\text { Elymus }\end{array}$ & $\begin{array}{l}37 \\
43 \\
18\end{array}$ & $\begin{array}{l}17 \\
16 \\
21\end{array}$ & $\begin{array}{l}7.9^{* *} \\
3.3^{* *} \\
6.1^{* *}\end{array}$ & $\begin{array}{l}.79 * * \\
.58^{* *} \\
.71^{* *}\end{array}$ & $\begin{array}{l}2.4 \\
1.7 \\
3.5\end{array}$ & $\begin{array}{l}1.0 \\
0.7 \\
1.5\end{array}$ \\
\hline
\end{tabular}

**Values significantly different from zero at $P<.01$.

'Group I genera include Thinopyrum, Agropyron, and Pseudoroegneria.

${ }_{2}$ Group II genera include Critesion, Hordeum, Psathyrostachys and Leymus.

4). Slopes for genera within a group were not different $(P<.06)$; however, slopes between groups were different $(P<.05)$.

Group 1, contained the Pseudoroegneria, Thinopyrum, and Agropyron genera (traditional wheatgrasses). This group accumulated silicon at a faster rate in leaves $(P<.05)$ than group 2, which contained the Critesion, Hordeum, Psathyrostachys and Leymus genera (wild barley and wildrye) (Table 4). The Elymus group was intermediate in silicon accumulation rate and did not differ $(P<.05)$ from Thinopyrum and Agropyron genera in group 1 or Critesion in group 2 . Leaves of groups 1 and 2 had similar concentrations of silicon at the vegetative stage of maturity with values of 17 and $16 \mathrm{mg} \mathrm{Si} / \mathrm{g}$, respectively. However, at the seed-ripe stage these concentrations had increased to 49 and $29 \mathrm{mg} \mathrm{Si} / \mathrm{g}$, respectively. At the vegetative state $(x=0)$ the Elymus genus contained 21 $\mathrm{mg} \mathrm{Si} / \mathrm{g}$ and this increased to $45 \mathrm{mg} \mathrm{Si}$ by the seed-ripe stage.

The wheatgrasses (group 1) generally reach physiological maturity quicker than wildryes (with the exception of Russian wildrye) and wild barleys (group 2). Group 1 plants tend to have fewer leaves, which on the average may be chronologically older than leaves on group 2 plants. These older leaves of group 1 plants may have higher concentrations of silicon because passively-transported silicon (taken up as a soluble component in the transpiration stream) had a longer time to accumulate in the leaves. In contrast, group 1 may differ from group 2 because of differences in active transport (requiring energy) of silicon from roots to the leaves. This latter hypothesis may be very real, but was outside the scope of the present study.

\section{Silicon in Plant Parts}

Comparison of silicon concentrations in plant parts could only be done at the soft dough stage. Concentrations were highest in leaves, intermediate in inflorescences, and lowest in stems (Fig. 1). This may be the same order as water loss by transpiration.

Silicon could be distributed differently in other gramineae. Handreck and Jones (1968) reported silicon concentrations and contents of various plant parts in oats. Leaves had higher concentrations of silicon than stems. The various parts of the mature inflorescence contained up to $5 \mathrm{mg} \mathrm{Si} / \mathrm{g}$ tissue and about $70 \%$ of the total silicon in the aboveground portions of the oat plant. The large amount of silicon in the oat panicle may occur because it has an open structure and large surface area to mass ratio. Indian ricegrass (not shown) has an anatomical structure similar to oats and contained 25,15 , and $9 \mathrm{mg} \mathrm{Si} / \mathrm{g}$ in the leaves, inflorescence and stem, respectively, at the anthesis stage. These silicon values were higher than those reported by Handreck and Jones (1968) for oats, but lower than those shown for equivalent plant parts of many other grasses (Fig. 1). These relatively lower silicon levels may explain the often higher grazing preference for Indian ricegrass when compared with many other grasses.

Silicon concentrations in leaves of Pseudoroegneria (bluebunch wheatgrass and related species) were greater $(P<.05)$ than in leaves of Hordeum and Leymus genera (Fig. 1). Silicon concentrations and differences in silicon in heads and stems of the several genera tested are also shown in Figure 1.

\section{Silicon in Leaf Fiber Residues}

The proportion of total leaf silicon recovered in leaf fiber residues increased with increasing plant maturity (Table 5). The amount of silicon retained in the ADF residue (Table 5) was

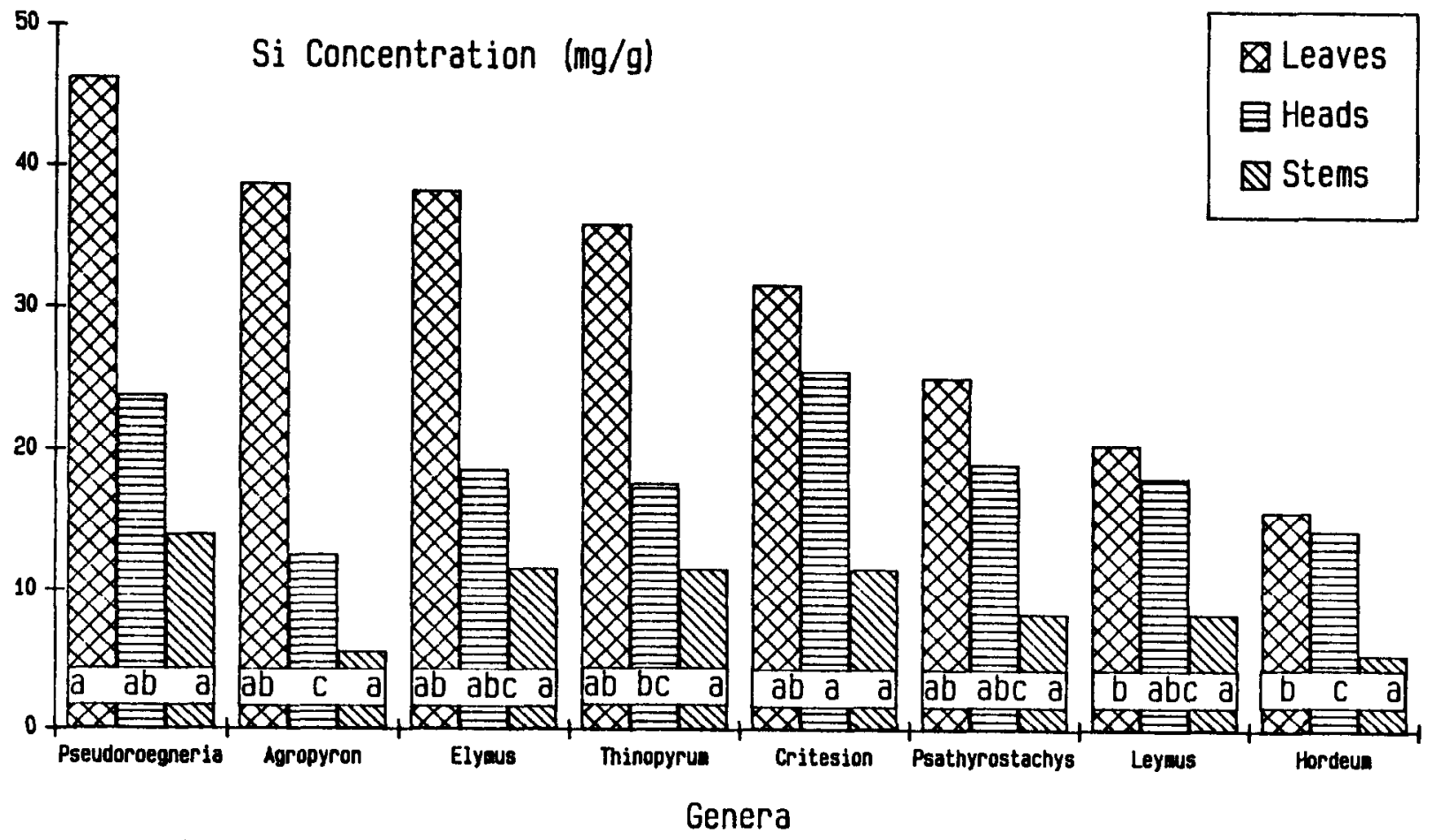

Fig. 1. Silicon concentrations ( $\mathrm{mg} / \mathrm{g}$ plant part) of leaves, heads, and stems of 8 grass genera at the soft dough stage. Silicon concentrations, within a given plant part, that do not have a common small letter are different $(\mathrm{P}<.05)$. 
Table 5. Forage quality traits and slicon distrubtion' in leaves of 20 grass accessions harvested at each of 6 phenolopical stages.

\begin{tabular}{|c|c|c|c|c|c|c|}
\hline \multirow[b]{2}{*}{ Phenological stage } & \multirow{2}{*}{$\begin{array}{c}\text { Acid detergent } \\
\text { fiber } \\
\text { (ADF) }\end{array}$} & \multirow{2}{*}{$\begin{array}{c}\text { Neutral detergent } \\
\text { fiber } \\
\text { (NDF) }\end{array}$} & \multirow{2}{*}{$\begin{array}{l}\text { Estimated dry } \\
\text { matter } \\
\text { digestibility }\end{array}$} & \multicolumn{3}{|c|}{ Silicon } \\
\hline & & & & Total & $\begin{array}{c}\text { ADF } \\
\text { insoluble }\end{array}$ & $\begin{array}{c}\text { NDF } \\
\text { insoluble }\end{array}$ \\
\hline & & & $(\mathrm{mg} / \mathrm{g} \mathrm{d}$ & tissue)-__ & & \\
\hline $\begin{array}{l}\text { Vegetative } \\
\text { Boot } \\
\text { Anthesis } \\
\text { Soft dough } \\
\text { Seed-ripe } \\
\text { Regrowth }\end{array}$ & $\begin{array}{l}210 \pm 34 \\
280 \pm 35 \\
320 \pm 29 \\
350 \pm 31 \\
390 \pm 32 \\
270 \pm 33\end{array}$ & $\begin{array}{l}440 \pm 47 \\
470 \pm 59 \\
500 \pm 37 \\
540 \pm 38 \\
580 \pm 52 \\
470 \pm 72\end{array}$ & $\begin{array}{l}544 \pm 41 \\
495 \pm 46 \\
455 \pm 39 \\
427 \pm 40 \\
378 \pm 50 \\
502 \pm 77\end{array}$ & $\begin{array}{l}17 \pm 4.7 \\
22 \pm 6.1 \\
29 \pm 7.0 \\
30 \pm 11.2 \\
40 \pm 13.1 \\
22 \pm 7.4\end{array}$ & $\begin{array}{l}13 \pm 3.7 \\
16 \pm 4.2 \\
21 \pm 5.1 \\
24 \pm 9.3 \\
30 \pm 10.8 \\
21 \pm 6.1\end{array}$ & $\begin{array}{r}5.6 \pm 1.9 \\
6.5 \pm 2.3 \\
9.8 \pm 3.7 \\
10.8 \pm 5.6 \\
15.0 \pm 6.1 \\
7.9 \pm 2.8\end{array}$ \\
\hline
\end{tabular}

'Means \pm standard error of mean.

"Accessions are those designated by the "3" footnote on Table 2.

generally twice that in the NDF residue. This reflects the polymerization of more plant silicon upon exposure to strong acid $(\mathrm{pH}$ about 1) in the ADF extractant. Silicon was the main component in ashed-ADF residue $[360 \pm 47(\mathrm{SE}) \mathrm{mg} / \mathrm{g}]$ and $\mathrm{NDF}$ residue $[276$ \pm 79 (SE) $\mathrm{mg} / \mathrm{g}]$, across all species and phenological stages. Total leaf silicon and that insoluble in the ADF or NDF extractions were significantly correlated $(P<.01)$ at all except the regrowth stage, where correlations were only significant at $P<.15$ level.

\section{Silicon Ingestion by Ruminants}

These results and others by Bailey (1976) and Parker (1957) illustrate that herbivores can consume large amounts of silicon that has been taken up by plants. Endogenous silicon (taken up by the plant) may be more active in reducing forage quality (Mika 1986) than exogenous silicon occurring as dust on plants or that associated with ingested soil. Cattle can potentially ingest large amounts of soil (Mayland et al. 1977) which can provide up to $300 \mathrm{~g}$ $\mathrm{Si} \bullet \operatorname{cow}^{-1} \bullet \mathrm{day}^{-1}$. This silicon is probably insoluble at the physiological pH of the rumen. Jones and Handreck (1967) noted that only a minor portion of ingested exogenous silicon is dissolved in passing along the alimentary tract. They did not provide any detailed information about the solubilization of soil-silicon in the rumen.

\section{Analytical Reference}

The barley-straw reference sample analyzed with each batch of unknowns contained a mean of $19.7 \pm 1.2(\mathrm{SE}) \mathrm{mg} \mathrm{Si} / \mathrm{g}$. This value is compared with $20.0 \pm 0.8$ (SE) determined by another laboratory using the same procedure. Therefore the analysis of silicon was considered to be within acceptable precision tolerances.

\section{Estimated Digestibility}

Concentrations of anti-quality factors (ADF, NDF, and silicon) in grass leaves increased with advancing plant maturity (Table 5). Leaf EDMD decreased as physiological age of the plant increased.

Silicon may act as a structural component or "varnish" on cell walls. This would prevent or delay accessibility of rumen microorganisms to cell contents (Harbers et al. 1981). Van Soest and Jones (1968) suggested that both total silicon and, more importantly, soluble silicon decreased in vivo organic matter digestibility. Smith and Urquhart (1975) reported in vitro digestibility of semiarid grasses was decreased by silica. Water-soluble silicon inhibits the activity of cellulases and other digestive enzymes, whereas insoluble forms are chemically inert (Mika 1986, Shimojo and Goto 1985). Authors are generally in agreement that silicon decreases forage quality, but few of the studies have considered the contributions of silicon simply as an inert component. To accomplish this, digestibility should be reported on an ash-free basis.

It is our opinion that soluble silicon might complex with an element, like zinc, limiting its supply to rumen microorganisms. This elemental deficiency would limit microbial growth and production of cellulytic enzymes, and ultimately reduce organic mat- ter digestibility (R.J. Moir, Univ. of Western Australia, Nedlands, personal communication).

\section{Sheep Preference}

Relative preference scores of the 31 accessions (Study II) and 5 growth stages were subjected to analysis of variance. Preference scores differed between species and within growth stages $(P<.01)$, which supports the premise that preference changes with season of use (Table 2). 'Latar' orchardgrass was the most preferred accession when compared across all stages. 'Nezpar' Indian ricegrass was only moderately preferred, although in Study I it was highly preferred. The difference in seasons, age and class of animals, and the experimental design (row seeding versus spaced plants) might explain some differences in preference. The grazing periods were chosen to correspond to the phenological growth stages of the Agropyrons. Not all plants were at the same phenological stage during grazing periods. By describing the periods in this manner, there was undoubtedly some bias added to the ranking of the other grasses. It is interesting that bluebunch wheatgrasses were generally less preferred than the crested wheatgrasses. Preference scores of some of the wildryes were less than expected. It is evident that interactions between preference and sites, soils, seasons, and different classes of livestock occur.

In general, genotypes expected to have low preference by cattle (authors' experience) were also ranked low by sheep in this study. Conversely, those highly preferred by cattle were also highly preferred by sheep. There are several exceptions to the ranking noted either in comparison with data in Tables 1 and 2 or from experience. For example, the rankings of Indian ricegrass and the 2 squirreltails seem to be different than expected. The Russian wildryes, Psathyrostachys juncea, were moderately preferred at the bōot stage. Relative preference doubled from the vegetative to the boot stage for both Russian wildryes, and then dropped in preference at anthesis to about the same level as at boot stage, contrary to Study I. The wildryes now classified as Leymus had consistently low preferences across all growth stages. We are unable to explain these findings.

\section{Silicon and Preference Score}

Preference scores in Study II were not related to soluble or insoluble silicon in the ADF and NDF residue, nor to total silicon at any of the phenological stages. Preference scores were similarly not related to total silicon in Study I. Thus, sheep preference for these grasses was a function of factors other than silicon components. In Study II, EDMD values were positively related $(\boldsymbol{P}<.05)$ to preference scores across all accessions at the boot and anthesis stages. Variation in EDMD values accounted for $48(P<.001)$ and $32 \%(P<.01)$ of the variability in preference at the 2 growth stages, respectively. 


\section{Harshneas and Preference}

Leaf:stem ratios at anthesis and soft dough averaged $.51 \pm .34$ (SE) and .55 \pm .27 (SE), respectively. These ratios were not significantly different from those at the seed-ripe stage. The leaf:stem ratios were positively related with preference scores accounting for $13(P<.10)$ and $27 \%(P<.05)$ of the variation in scores at the anethesis and soft dough stages, respectively. Murray (1984) also evaluated sheep utilization of many of these same accessions and found that preference was positively related to the proportion of leaves present. Utilization decreased as the proportion of reproductive tillers increased.

Harshness scores for 22 accessions were negatively related to preference scores at seed-ripe stage $(r=-.69, P<.05)$. Harshness was determined at a single growth stage in this study, but has been used in other studies to evaluate palatability. Hanna et al. (1974) showed that cattle preferred the trichomeless pearl millet over accessions with trichomes. Marten (1970), in his review of forage palatability, noted that several orchard grass breeders had selected against harshness or, more specifically, the silicified dentations on the leaf edges. The harhness score method combined with other aspects of palatability could have potential for preference estimation and plant selection of C-3 grasses.

\section{Conclusions}

Silicon concentrations in leaves increased with advancing phenological maturity. Silicon concentrations were greatest in leaves, intermediate in inflorescences, and least in stems.

Leaf silicon concentrations of some genera increased at distinctly different rates as plants matured. Whether this was a result of a greater rate of uptake in the first group, or whether the second group continued to develop new leaves with a net lower concentration of silicon, was not determined.

Ratings of sheep grazing preference for the grasses varied according to phenological stage. These findings support the conclusion that preference can change with season of use. Preference scores, at specific phenological stages, were positively related to the EDMD and leaf:stem ratio of the accessions and negatively related to estimates of leaf harshness. Preference was not related to measures of silicon or ADF and NDF and their respective silicon contents.

Silicon was nearly twice as soluble in the NDF extractant as in the ADF extractant. This is attributed to polymerization of silicon at the very low pH of ADF extraction. The NDF extractant is buffered at near neutral and thus is more like the rumen conditions. Nevertheless, it would be interesting to determine the solubility of forage silicon fractions in vivo.

\section{Literature Cited}

Bailey, C.B. 1976. Effects of ammonium chloride on formation of siliceous urinary calculi in calves. Can. J. Anim. Sci. 56:359-360.

Blackman, E., and C.B. Bailey. 1971. Dissolution of silica from dried grass in nylon bags placed in the rumen of a cow. Can. J. Anim. Sci. 51:327-332.
Dewey, D.R. 1984. The genomic systems of classification as a guide to intergeneric hybridization with the perennial triticeae. p. 209-279. In: J.P. Gustafson (ed) Gene manipulation in plant improvement. Plenum Publishing Corp. New York.

Fox, R.L., J.A. Silva, D.L. Plucknett, and D.Y. Teranishi. 1969. Soluble and total silicon in sugar cane. Plant and Soil 30:81-84.

Goering, H.K., and P.J. Van Soest. 1970. Forage fiber analysis (apparatus, reagents, procedures, and some applications). USDA Agr. Handb. 379.

Handreck, K.A., and L.H.P. Jones. 1968. Silica content of plant parts in relation to stage of growth supply of silica and transpiration. IV. In: Studies of silica in the oat plant. Plant and Soil 29:449-459.

Hanna, W.W., W.G. Monson, and G.W. Burton. 1974. Leaf surface effects on in vitro digestion and transpiration in isogenic lines of sorghum and pearl millet. Crop Sci. 14:837-838.

Harbers, L.H., D.J. Raiten, and G.M. Paulsen. 1981. The role of plant epidermal silica as a structural inhibitor of rumen microbial digestion in steers. Nutr. Rep. Int. 24:1057-1066.

Jarvis, S.C. 1987. The uptake and transport of silicon by perennial ryegrass and wheat. Plant and Soil 97:429-437.

Jones, L.H.P., and K.A. Handreck. 1967. Silica in soil, plants and animals. Adv. Agron. 19:107-149.

Marten, G.C. 1970. Measurement and significance of forage palatability. p. D1-D55. In: R.F. Barnes, D.C. Clanton, C.H. Gordon, and T.J. Klopfenstein (eds). Proc. Nat. Forage Conf. In Forage Quality Evaluation and Utilization. Nebraska Center Continuing Education, Lincoln.

Mayland, H.F., G.E. Shewmaker, and R.C. Bull. 1977. Soil ingestion by cattle grazing crested wheatgrass. J. Range Manage. 30:264-265.

McNaughton, S.J., J.L. Tarrants, M.M. McNaughton, and R.H. Davis. 1985. Silica as a defense against herbivore and a growth promoter in African grasses. Ecology 66:528-535.

Mikn, V. 1986. The effect of the water-soluble form of silicon in fodder crops on their digestibility. Sci. Agr. Bohemoslovaca 18:185-190.

Moore, D. 1984. The role of silica in protecting Italian ryegrass (Lolium multiflorum) from attack by dipterous stem-boring larvac (Oscinella frit and other related species). Ann. Appl. Biol. 104:161-166.

Murray, R.B. 1984. Yields, nutrient quality, and palatability to sheep of fourteen grass accessions for potential use on sagebrush-grass range in southestern Idaho. J. Range Manage. 37:343-348.

Parker, K.G. 1957. "Water-belly" (urolithiasis) in range steers in relation to some characteristics of rangeland. J. Range Manage. 10:105-111.

SAS Institute Inc. 1985. The GLM procedure, p. 433-506. In: SAS user's guide: Statistics, Version 5 Edition. Cary, N.C.

Shimojo, M., and I. Goto. 1985. Effect of soluble silica on digestion of forage with rumen fluid of goat and cellulase. Japanese. J. Zootechnical Sci. 56:20-24.

Smith, G.S., and A.B. Nelson. 1975. Effects of sodium silicate added to rumen cultures on forage digestion, with interactions of glucose, urea and minerals. J. Anim. Sci. 41:891-899.

Smith, G.S., A.B. Nebon, and E.J.A. Bozgino. 1971. Digestibility of forages in vitro as affected by content of silica. J. Anim. Sci. 33:466-471.

Smith, G.S., A.L. Neumann, V.H. Gledhill, and C.A. Arzola. 1973. Effects of "soluble silica" on growth, nutrient balance and reproductive performance of albino rats. J. Anim. Sci. 36:271-278.

Smith, G.S., A.L. Neumann, A.B. Neleon, and E.E. Ray. 1972. Effects of "soluble silica" upon growth of lambs. J. Anim. Sci. 34:839-845.

Smith, G.S., and N.S. Urquhart. 1975. Effect of sodium silicate added to rumen cultures on digestion of siliceous forages. J. Anim. Sci. 41:882-890.

Steele, R.G.D., and J.H. Torrie. 1960. Linear regression. p. 173. In: Principles and procedures of statistics. McGraw-Hill Book Company, Inc., New York.

Van Soeat, P.J., and L.H.P. Jones. 1968. Effect of silica in forages upon digestibility. J. Dairy Sci. 51:1644-1648. 